\title{
Cooperative Approach: A Survey on Students' Preferred Classroom Activities in Reading Classes at Thu Dau Mot University
}

\section{Hong Thi Xuan Nguyen, Du Thanh Tran ${ }^{+}$}

\section{Article history}

Received: 09 August 2021

Accepted: 10 November 2021

Published: 03 December 2021

\section{Keywords}

Attitudes, motivation, reading, classroom activities, cooperative learning approach

\author{
Thu Dau Mot University, Vietnam \\ ${ }^{+}$Corresponding author • Email: dutt@tdmu.edu.vn
}

\section{INTRODUCTION}

Today, English plays an important part in Vietnam's educational system. It is taught in various schools, from elementary schools to universities and even at post-graduate level, and widely used in business. It is considered a key to success as well as a means to improve people's knowledge in many aspects of our society. All over Vietnam, the number of English language learners has been rapidly increasing. English has become an important tool for international integration in Vietnam. Owing to its importance, how to motivate learners to study the language or know how to study the language effectively is still every English teacher's main concern nowadays.

Enhancing students' motivation in learning languages by using cooperative instructions is frequently popularized with different classroom activities, especially groupwork (Marzban \& Akbarnejad, 2013; Pan \& Wu, 2013). However, it is essential to confirm that this method does not merely mean asking students to work in groups during the lesson; it refers to students' cooperation in activities that are highly organized so that all members will gain a common goal (Ashman \& Gillies, 2003).

In language teaching and learning, reading comprehension is considered one of the most important skills that a student should master. It is, therefore, necessary for teachers to seek appropriate activities in their reading classes. Like other lessons, various types of group-work activities might be held in Reading classrooms to motivate students' interests in accordance with teachers' experience. For example, group discussions, group presentations, group assignments, and jigsaw activities are often used to promote students' contribution and motivation to the learning process. 
Moreover, based on the belief that reading can itself derive a kind of intrinsic motivation from students' own interests if it is led in a proper way (Cambria \& Guthrie, 2010), the writers are puzzled whether these group-work activities are able to develop students' actual interest in reading activities instead of merely the passing-exam purpose.

Currently, the English Language Program for English majors at Thu Dau Mot University (TDMU) consists of four Reading courses, which are continuously connected. The courses aim at developing and fulfilling students' reading comprehension skills, named Essential Reading, Reading Strategies, Academic Reading, and Critical Reading. These courses are aligned to the course books Q-Skills Reading and Writing 2 to 5. The courses sharpen students' English competence with IELTS orientation so that students are able to catch up with the social trend. The first course is called Essential Reading and Writing, aligning to the course book Q-Skills Reading and Writing Skills 2. The course is allocated in the first semester, guiding new college students to familiarise themselves to the learning style at university. This helps students to deal with long reading texts, which are different from simpler ones in high school course books. The second course targets to improve students' reading skills, enrich their vocabulary budget, and form reading techniques. The course is expected to establish students' solid foundation of English reading comprehension skills. The third course sharpens students' reading competency in a wider range of topics in academic fields. Students practice their English with different kinds of scientific topics. The fourth course enhances students' critical reading skills. This course encourages students to apply their critical thinking skills to reading activities. They are expected to read actively, commenting and evaluating the documents they have read, which also helps students to develop their researching skills. In general, the four reading courses are designed to establish and promote students' reading comprehension skills to prepare students' linguistic competence for further studies (Faculty of Foreign Languages, 2020).

Although the research on applying the Cooperative approach in reading lessons at TDMU has not been clearly shaped, reading lessons contain various types of group-work activities thanks to the teachers' personal experience. In fact, group discussions, group presentations, group assignments, and jigsaw activities are often used to encourage students' contributions to classroom activities. Regarding reading as a crucial skill to one's life in numerous ways, from getting information to entertaining their minds, the teachers have offered plenty of chances for students to bring their preferred topics and reading materials to class during the courses. Based on the belief that reading can itself derive intrinsic motivation from students' own interests if it is led properly (Cambria \& Guthrie, 2010), the teachers aimed to investigate students' favourite learning activities in the reading classes and the influence of these activities on students' reading habits.

A great number of studies have proved that motivation functions as a key factor in learning a foreign or second language (Cambria \& Guthrie, 2010; Dörnyei \& Ushioda, 2013). Except for the case of children absorbing their first language, Ushioda (2010) stated that adults' willingness and achievement of learning a second language are significantly affected by how much they are motivated. Over time, learning motivation has been developed into various forms, which aims at making language acquisition more effective, such as intrinsic or extrinsic, integrative or instrumental, etc.

Upon the foregoing background, this paper aims at investigating activities that draw students' attention and interests in reading, and whether or not the lessons can, to some extent, create the love for and foster a habit of reading in English outside the classroom. The main purposes of the study are to find out (i) students' attitudes towards reading activities; (ii) what classroom activities they prefer and (iii) students' expectations from the course.

\section{LITERATURE REVIEW}

\subsection{Theoretical Background}

Motivation in Language Learning: Motivation is defined as some kind of internal drive, impulse, emotion, or desire that encourages somebody to pursue a course of a particular action, which can be situational or task-oriented (Brown, 1990, 2007; Harmer, 1991). Another definition of motivation is that it is the process of arousing, directing, and maintaining behavior over time (Huang 2007). Psychologists define motivation in terms of certain needs. Motivation is thought of as a psychological concept in human behavior that describes a predisposition toward a particular behavior to satisfy a specific need. One theory involved in motivation is Maslow's Hierarchy of Needs (1954), focusing on an individual's specific desires and how they motivate that individual. Maslow's theory states that when a need is unfulfilled, the individual will be motivated to fulfill that need. Once lower-level needs are satisfied, higher-level needs can be addressed and the individual will be motivated to satisfy those needs. If one of 
the lower needs is suddenly not satisfied, then this need will suddenly become the most important need until it is again satisfied.

It is undeniable that the learning process is much influenced by motivational factors. Historically, Biggs (1987) believed that extrinsic motivation occurs when a student deeply understands what benefits they might gain from the tasks, whereas intrinsic motivation occurs when the student himself/herself loves to join the activities. Then Gardner (2007) found that integration of attitudes toward learning situations and instrumental orientation has a positive influence on motivation and indirectly affects students' learning results. From another view, Kauffman and Shell (2012) have proved that learning happens when the transference and connection of input information and prior knowledge occurs. The evidence has proved that there is a correlation among students' own background, their interests in a specific field, and the classroom activities, which all contribute to the success of the learning process.

According to Brown (1990, 2007), a learner will be successful with proper motivation. Brown (2007) claims that learning a foreign language clearly requires some student's motivation which has mainly been used to refer to the long-term attitudes in the students' minds. Some students are more likely to want to learn than others in a given learning situation obviously because of their different motivations to learning (Cook, 2001). Student motivation is imperative in a classroom to enhance the students' learning experience (Armstrong \& Baron, 1998). It is obvious that strong student motivation and engagement in learning have consistently been linked to reduced dropout rates and increased levels of student success (Blank, 1997; Dev, 1997; Kushman et al., 2000). Student motivation relates to many factors which require a great deal of effort from any instructors who want to stimulate their students to learn better because every student is unique in their own way. This uniqueness is expressed through the personality that can be shown through perceptions, attitudes, interests, feelings, and personal traits.

Specifically to the case of English reading lessons at TDMU, motivation is counted as learners' attitudes, desires, and participation willingness upon Cambria \& Guthrie (2010).

Cooperative Learning: Being considered an effective approach that boosts students' involvement in classroom activities, cooperative instruction is a set of teaching and learning activities in which students are assigned in groups and collaborate to achieve common goals (Johnson et al., 1998). Recently, it is popularized to enhance reading comprehension, and believed to contribute much to the learning process by affecting learning motivation (Tsay \& Brady, 2022; Pan \& Wu, 2013; Marzban \& Akbarnejad, 2013; Farzaneh \& Nejadansari, 2013). Often, Cooperative learning approach includes classroom activities such as Jigsaw, Student Teams-Achievement Division, Group Investigation or Learning Together, etc. (Slavin, 1991).

Reading Comprehension: Kırmız (2010) synthesized reading comprehension as the process of transferring and combining the background knowledge and the message from the input materials, then the final goal - comprehension will be achieved under the application of various different strategies. In other words, reading comprehension is affected by numerous factors, among which the contribution of individuals to the successful reading lessons is particularly emphasized in the paper.

Frequently-used activities in reading comprehension classes: Research has shown that reading learning has various definitions: reading activities in class were generally set up through the application of a series of segregated skills such as finding main ideas, sequencing, contrasting and comparing, identifying information, guessing meaning in context, etc., and the proficiency of these skills was viewed as good comprehension skills (Texas Education Agency, 2019). However, "Real reading has to do with thinking, learning, and expanding a reader's knowledge and horizons. It has to do with building on past knowledge, mastering new information, and connecting with the minds of those you've never met." (Zimmerman \& Hutchins, 2003). Real reading comprehension requires a mixture of many competencies and the connection between previous background and input information. That reality pushes instructors in reading comprehension classes to find ways to organize varieties of tasks, activities to enhance students' outcomes. Consenquently, they might apply traditional types of exercises and trendy ones in their lessons.

\subsection{Previous studies}

The article only mentions selected papers in the last decade which describe the relationship between motivation in reading comprehension and cooperative learning $(\mathrm{CL})$ strategies.

Identifying the value of cooperative strategies in reading comprehension lessons, Kirmız1 (2010) sought the correlation between reading techniques and time spent on reading outside class. This paper concluded that reading every day sharpened students' skills, and the skills encouraged students to read and nourish a habit of using the strategies in the long-term process. In the same trend, Zarei (2012) measured the influence of Student TeamsAchievement Divisions' (STAD) and 'Cooperative Integrated Reading and Composition (CIRC) - cooperative 
learning models on EFL (English as Foreign Language) learners' success. The study indicated that cooperative language learning had a significant effect on the learning and teaching process. Another experimental study by Pan and $\mathrm{Wu}$ (2013) investigated the influence of CL on enhancing first-year English students' motivation. The research found out that group discussion in the reading classroom based on CL instruction effectively motivated the students' learning process. Adding to this, in an article from Iran, the writers concluded that cooperative reading strategies have a striking influence on students' progress both in language and social skills (Marzban \& Akbarnejad, 2013). On the other hand, while numerous studies concentrated on the influence of CL, this paper highlighted students' personal opinions on how much they preferred to apply this method in their learning process, and the result showed that the respondents had a positive attitude towards implementing CL strategies in their classroom. Consequently, it also increased students' interest in their learning process (Farzaneh \& Nejadansari, 2014). Finally, a recent study investigated the influence of implementing the CL model 'Number Head Together' in teaching reading comprehension, and it pointed out that the method encouraged students to join in classroom activities, and helped the students gain much better results (Alipour, Tabrizi \& Famian, 2016). Hanjani \& Li (2017) confirmed the efficiency of applying Cooperative learning strategies in classes of English as a Foreign Language. Rahmi \& Marnola (2020) stated applying the cooperative learning approach in reading comprehension activities can help to enhance student's results.

From the results of the above papers, it is said that there is a correlation among the following factors: CL strategies, learning motivation, and reading comprehension. In the scope of this paper, the focused question of the study is whether CL in the form of group discussion in reading lessons can foster the love for and build up a culture of reading in English among the students.

\section{MATERIALS AND METHODS}

This section outlines the methodology of the study, including the information about the participants, the research design, the instruments, and the research procedure.

Participants: The participants are 81 ESL students of the English Faculty at Thu Dau Mot University in the academic year 2020-2021. They were chosen due to specific features. They are fourth-year students with sufficient reading strategies, experienced in numerous classroom activities like pair work, group work, giving presentations, jig-saw reading, and so on. Thus, their responses to the activities in the role of learners can be considered to be reliable in the research case.

Design of the Study: The paper employed a survey questionnaire that aims to describe students' attitudes towards current classroom activities in reading lessons at TDMU, and figure out whether there is a connection between these group activities and the level of interest in reading English materials outside class. So, this study seeks the answers to the three main questions: (1) What are students' attitudes towards reading activities?; (2) What classroom activities do they prefer?; (3) What outcome can students gain from the course?.

Instruments: The questionnaire employed in this study consists of thirteen mixed questions, aiming at investigating students' attitudes to reading lessons and exploiting students' interest levels on activities they have experienced during their lessons. The students chose their choices and voted for suggested activities using the Likert scale. The questionnaire were piloted and adjusted a couple of times before the actual survey.

Procedure: The questionnaires were sent to students by the teacher-in-charge or by the researchers themselves at the end of the 4th reading course at TDMU in the academic year 2020-2021. After two weeks, the responses were collected and analyzed via Excel and SPSS.

\section{RESULTS AND DISCUSSION}

The survey found that the participating students generally had some kind of motivation for English reading lessons, in the form of both extrinsic and intrinsic motivation. Besides, this study spotted students' preferred activities in English reading lessons and how they ranked them based on their own preference and gained learning results. Finally, it is proved that students' preferred activities could foster a love for reading to some extent.

Obviously, there is a certain level of fundamental motivation among the students in reading comprehension classes. Figure 1 shows that most students were aware of the necessity of reading in reality, with $75 \%$ of respondents claiming positive attitudes; however, Figure 2 indicates that just over half of the students said that they were really interested in the reading lessons. Therefore, the two pie charts imply that although the students recognized the value of the skill, it did not correlate with a high level of intrinsic motivation. Therefore, it was some kind of extrinsic 
motivation which triggered student's feelings that they needed to study for their specific purposes. Evidently, Figure 3 shows that over $90 \%$ of the students agreed that reading lessons were very and quite important. In brief, the three pie charts help to figure out the extrinsic and intrinsic motivation in reading lessons.
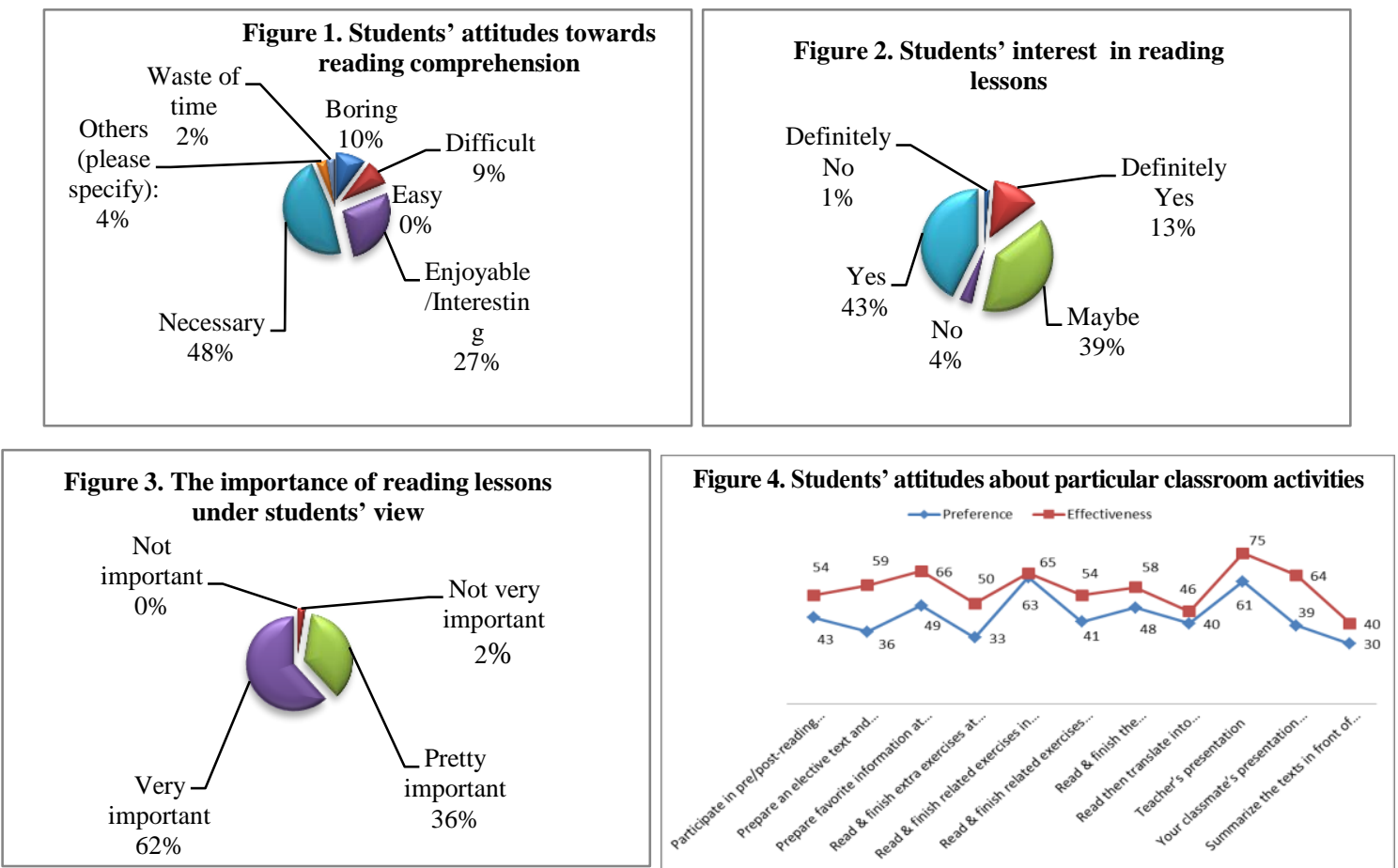

Table 1 shows the results of students' comments on the reading activities that they participated in during the lessons. The columns of preferences and effectiveness indicate the total numbers of responses at levels 4 and 5 of the Likert scale. 'Preferences' refers to the level that students voted for regarding their favorite activities, and 'effectiveness' refers to the scale that the respondents chose regarding how helpful the class activities were for their learning results. The table indicates that students were interested in several group activities, and they also preferred activities based on teachers' leading and activities to develop reading strategies, but as predicted, they did not enjoy homework and several similar activities. Specifically, the cooperative-learning activities which include teamwork and jigsaw techniques received a strikingly good evaluation - $73 \%$ and $81 \%$ for effectiveness. More interestingly, the correlation number in table $3(0.6<\mathrm{r}=0.781$ and sig. $<5 \%)$ and the line graph (Figure 4$)$ show that there was a strong correlation between students' interests and their effectiveness. The activities proved to be effective when the respondents liked them and vice versa.

\section{Table 1. Students' preferred classroom activities}

\begin{tabular}{lcccc}
\hline \multicolumn{1}{c}{$\begin{array}{c}\text { How would you rate each of the } \\
\text { following learning activities? }\end{array}$} & \multicolumn{2}{c}{ Preferences } & \multicolumn{2}{c}{ Effectiveness } \\
\cline { 2 - 5 } & Respondents & Percentage & Respondents & Percentage \\
\hline Participating in pre/post-reading activities & 43 & 53,09 & 54 & 66,67 \\
\hline $\begin{array}{l}\text { Preparing an elective text and related tasks } \\
\text { in groups at home then sharing with your } \\
\text { classmates (you are in role of an instructor) }\end{array}$ & 36 & 44,44 & 59 & 72,84 \\
\hline $\begin{array}{l}\text { Preparing favorite information at home in } \\
\text { groups (stories, news, characters, events...) } \\
\text { then sharing with other groups members in } \\
\text { class (you tell the other group members } \\
\text { and listen to their information) }\end{array}$ & 49 & 60,49 & 66 & 81,48 \\
\hline
\end{tabular}


Reading \& completing extra exercises at home (answering the questions/ True or

False...)

\begin{tabular}{|c|c|c|c|c|}
\hline $\begin{array}{l}\text { Reading \& completing related exercises in } \\
\text { groups }\end{array}$ & 63 & 77,78 & 65 & 80,25 \\
\hline $\begin{array}{l}\text { Reading \& completing related exercises } \\
\text { individually }\end{array}$ & 41 & 50,62 & 54 & 66,67 \\
\hline $\begin{array}{l}\text { Reading \& completing the comprehension } \\
\text { tasks in class (answering the questions/ } \\
\text { True or False...) }\end{array}$ & 48 & 59,26 & 58 & 71,60 \\
\hline Reading then translating into Vietnamese & 40 & 49,38 & 46 & 56,79 \\
\hline Teacher's presentation & 61 & 75,31 & 75 & 92,59 \\
\hline $\begin{array}{l}\text { Your classmate's presentation (Several } \\
\text { slides for introducing the topic before the } \\
\text { main lesson) }\end{array}$ & 39 & 48,15 & 64 & 79,01 \\
\hline Summarizing the texts in front of the class & 30 & 37,04 & 40 & 49,38 \\
\hline
\end{tabular}

Table 2. Correlations between the comment on preferences and effectiveness

\section{Correlations}

\begin{tabular}{llcc}
\hline & & Preferences & Effectiveness \\
\hline \multirow{5}{*}{ Preferences } & Pearson Correlation & 1 & $.781^{* *}$ \\
& Sig. (2-tailed) & & .005 \\
& $\mathrm{~N}$ & 11 & 11 \\
& Pearson Correlation & $.781^{* *}$ & 1 \\
Effectiveness & Sig. (2-tailed) & .005 & 11 \\
& $\mathrm{~N}$ & 11 & \\
\hline
\end{tabular}

**. Correlation is significant at the 0.01 level (2-tailed).

The results from Table 3 satisfy but puzzle the researchers. It indicates that the students' love for reading was boosted to $42 \%$ from $15 \%$. The difference of $27 \%$ strikes a beautiful mark which is strong enough to conclude about the correlation between reading classroom activities and the love for reading. However, the other decreasing numbers - ranging from $2 \%$ to $11 \%$ - show that the students felt unsure about their achievements, which might be explained by a variety of reasons, and this encourages the writers to conduct another research.

Table 3. Students' expectation and achievements

\begin{tabular}{|c|c|c|c|c|c|}
\hline Items & $\begin{array}{l}\text { Why do you learn reading } \\
\text { comprehension skills? }\end{array}$ & Expectation & Expectation & Achievement & Achievement \\
\hline 1 & To pass university exam & 53 & $65 \%$ & 50 & $62 \%$ \\
\hline 2 & $\begin{array}{l}\text { To meet qualifications for your future } \\
\text { job }\end{array}$ & 57 & $70 \%$ & 54 & $67 \%$ \\
\hline 3 & $\begin{array}{l}\text { To master reading comprehension } \\
\text { techniques }\end{array}$ & 24 & $30 \%$ & 15 & $19 \%$ \\
\hline 4 & $\begin{array}{l}\text { To create a culture of reading in } \\
\text { English }\end{array}$ & 22 & $27 \%$ & 17 & $21 \%$ \\
\hline 5 & $\begin{array}{l}\text { To nourish the love of reading } \\
\text { information in English }\end{array}$ & 12 & $15 \%$ & 34 & $42 \%$ \\
\hline 6 & $\begin{array}{l}\text { To develop the habit of reading } \\
\text { information in English outside } \\
\text { classroom }\end{array}$ & 37 & $46 \%$ & 30 & $37 \%$ \\
\hline 7 & Others (please specify) & 2 & $2 \%$ & 0 & $0 \%$ \\
\hline
\end{tabular}


The above results adequately address the three questions of the study. Firstly, the findings have evidenced some existing motivation among the students in English reading comprehension lessons, in forms of both intrinsic and extrinsic motivation. This means that reading itself can draw students' interest, but the problem is what teachers themselves should do to maintain and enhance the participants' involvement. This finding is similar to Marzban \& Akbarnejad (2013)'s paper and Farzaneh \& Nejadansari (2014)'s conclusion. Secondly, the collected data include a list of classroom activities that students rated and ranked based on the level of interest and achievements. Most of them were group work and activities aiming at reading-strategy development. It is also clear that lectures were thoroughly evaluated, which promotes the researchers and the teachers' contribution to students' accomplishment. Collaborative activities attracted the participants during the lessons. More interestingly, although there were some differences, the comparison between interest level and activity effectiveness illustrates a general correlation, in which if students were interested in these activities, the activity effectiveness would be high. To some extent, the finding align with what Hanjani (2017) and Rahmi (2020) concluded - helping students to identify their needs before reading comprehension lessons could improve their outcomes. Thirdly, unlike the previous studies, the final finding indicates that there was a connection between classroom activities and the love of students in reading. Although students were not confident in achieving other objectives, they were sure to enhance the development of the love in reading with a striking difference. Hence, it is obvious that reading lessons can foster students' love in reading if the process is implemented properly, and the two other important goals - creativity of English reading culture and the habit of reading in English - will probably be gained when sufficient time has been invested.

\section{CONCLUSION}

This paper investigates English-majored students' favored activities in Reading classrooms to clarify student's learning motivation as well as their willingness to work in groups at TDMU. It is found that the students are interested in self-conducted activities, which can also foster students' love of reading. Consequently, it is suggested that instructors should consider selective learning activities for their reading comprehension classes to enhance students' learning outcomes. Like any other researches, the study has its own limitations. It is survey-based research to explore students' attitudes and measure their interests in specific existing classroom activities at TDMU. Although it achieved several useful results, it is essential to conduct further research for the application of CL strategies into the teaching and learning process.

Conflict of Interest: No potential conflict of interest relevant to this article was reported.

Funding: The authors received no financial support for this article.

\section{REFERENCES}

Alipour, S., Tabrizi, A. R. N., \& Famian, A. R. G. (2016). An Investigation of Differential Effects of Cooperative Learning Methods on Reading Comprehension of Iranian Students from High and Low Socioeconomic Status. Research Gate.

Armstrong, M., \& Baron, A. (1998). Performance Management: The New Realities. The Institute of Personnel and Development.

Ashman, A., \& Gillies, R. (2003). Cooperative learning: The social and intellectual outcomes of learning in groups. Routledge Falmer.

Biggs, J. B. (1987). Student Approaches to Learning and Studying. Research Monograph: ERIC.

Blank, W. (1997). Authentic Instruction. In W. E. Blank \& S. Harwell (Eds.). Promising Practices for Connecting High School to the Real World (pp. 15-21). Tampa, FL: University of South Florida (ERIC Document Reproduction Service No. ED 407 586).

Brown, H. D. (1990). M \& Ms. for Language Classrooms? An-other Look at Motivation. Georgetown University Round Table on Language and Linguistics. Ed. James E. Alatis. Washington.

Brown, H. D. (2007). Principles of Language Learning and Teaching (5th ed.). New York: Pearson Education.

Cambria, J., \& Guthrie, J. T. (2010). Motivating and Engaging Students in Reading. New England Reading Association Journal, 46(1), 16-29.

Cook, V. (2001). Second Language Learning and Language Teaching (3rd ed.). London: Edward Arnold.

Dev, P. C. (1997). Intrinsic Motivation and Academic Achievement: What Does Their Relationship Imply for the Classroom Teacher?. Remedial and Special Education, 18(1), 12-19. 
Dörnyei, Z., \& Ushioda, E. (2013). Teaching and researching: Motivation. Routledge.

Farzaneh, N., \& Nejadansari, D. (2014). Students' Attitude towards Using Cooperative Learning for Teaching Reading Comprehension. Theory and Practice in Language Studies, 4(2), 287-292.

Gardner, R. C. (2007). Motivation and Second Language Acquisition. Porta Linguarum.

Hanjani, A. M., \& Li, L. (2017). Cooperative Learning Pedagogy: A Response to an Urgent Need in the Iranian EFL Reading Comprehension Context. Journal of Teaching Language Skills (JTLS), 36(3), 33-58. https://doi.org/ 10.22099/jtls.2017.27008.2370

Harmer, J. (1991). The Practice of English Language Teaching. New York: Longman Publishing.

Huang, C. (2007). Why Do University Students Want to Learn English. Master Thesis, Providence University.

Johnson, D. W., Johnson, R. T., \& Smith, K. S. (1998). Cooperative Learning Returns to College. What Evidence is There that it Works? Change: the Magazine of Higher Learning, 30(4), 26-35.

Kauffman, D. \& Shell, D. F. (2012). The Unified Learning Model: How Motivational, Cognitive, and Neurobiological Sciences Inform Best Teaching Practices. Springer: Dordrecht, Netherlands.

Kırmızı, F. S. (2010). Relationship between Reading Comprehension Strategy Use and Daily free Reading Time. Procedia - Social and Behavioral Sciences, 2(2), 4752-4756.

Kushman, J. W., Sieber, C., \& Heariold-Kinney, P. (2000). This isn't the Place for Me: School Dropout. In Capuzzi, D \& Gross, D.R. (Eds.). Youth at Risk: A Prevention Resource for Counselors, Teachers, and Parents (3rd ed., 471-507). Alexandria, VA: American Counseling Association.

Marzban, A., \& Akbarnejad, A. A. (2013). The Effect of Cooperative Reading Strategies on Improving Reading Comprehension of Iranian University Students. Procedia - Social and Behavioral Sciences, 70, 936-942.

Maslow, A. H. (1954). Motivation and Personality. Harpers.

Pan, C.-Y., \& Wu, H.-Y. (2013). The Cooperative Learning Effects on English Reading Comprehension and Learning Motivation of EFL Freshmen. English Language Teaching, 6(5), 13-27.

Rahmi, Y., \& Marnola, I. (2020). Cooperative Integrated Reading and Compotion (CIRC). Journal of Elementary Education, 4(3), 662-672. https://doi.org/10.31004/basicedu.v4i3.406

Slavin, R. E. (1991). Student Team Learning: A Practical Guide to Cooperative Learning. ERIC.

Texas Education Agency (2019). What Research Tells Us About Reading, Comprehension, and Comprehension Instruction. Accessed from https://www.readingrockets.org/article/what-research-tells-us-about-readingcomprehension-and-comprehension-instruction

Tsay, M., \& Brady, M. (2012). A Case Study of Cooperative Learning and Communication Pedagogy: Does Working in Teams Make a Difference?. Journal of the Scholarship of Teaching and Learning, 10(2), 78-89.

Ushioda, E. (2010). Motivation and SLA: Bridging the gap. EUROSLA Yearbook, 10(1), 5-20. doi: https://doi.org/10.1075/eurosla.10.03ush

Zarei, A. A. (2012). The Effects of STAD and CIRC on L2 Reading Comprehension and Vocabulary Learning. Frontiers of Language and Teaching, 3(5), 161-173.

Zimmerman, S., \& Hutchins, C. (2003). Seven keys to comprehension: How to help your kids read it and get it! New York: Three Rivers Press. 